\title{
Increased circulating levels of betatrophin in individuals with long-standing type 1 diabetes
}

\author{
Daniel Espes • Joey Lau $\cdot$ Per-Ola Carlsson
}

Received: 9 July 2013 / Accepted: 13 September 2013 /Published online: 27 September 2013

(C) The Author(s) 2013. This article is published with open access at Springerlink.com

\begin{abstract}
Aims/hypothesis The hormone betatrophin was recently described as a potent stimulator of beta cell proliferation in mice. Insulin resistance, but not insulin deficiency, caused upregulation of betatrophin expression. If these findings were found to be fully applicable in humans, this would open up the possibility of future betatrophin treatment in type 1 diabetes. The present study measured for the first time betatrophin concentrations in humans and tested the hypothesis that there would be no difference in circulating betatrophin concentrations between patients with type 1 diabetes and healthy individuals.

Methods Betatrophin concentrations in plasma of 33 patients with type 1 diabetes and 24 age-matched healthy controls were measured by ELISA. The study participants were characterised for blood lipids, BMI, plasma glucose and $\mathrm{HbA}_{1 \mathrm{c}}$, and, for the diabetic patients, their insulin requirements and any residual C-peptide concentrations.

Results Plasma betatrophin concentrations were normally $\sim 300 \mathrm{pg} / \mathrm{ml}$, but were approximately doubled in patients with type 1 diabetes. In the patients, there were no correlations between betatrophin and age, blood lipids, BMI, glucose control or insulin requirement, whereas in controls betatrophin levels increased with age. BMI, blood pressure and triacylglycerol, LDL-cholesterol and HDL-cholesterol levels were similar in patients and healthy controls.

Conclusions/interpretation Circulating concentrations of betatrophin are increased in type 1 diabetes in contrast with what was recently described in an insulin-deficient mouse model. However, increased betatrophin concentrations do
\end{abstract}

D. Espes $(\bowtie) \cdot$ J. Lau $\cdot$ P.-O. Carlsson

Department of Medical Cell Biology, Uppsala University,

Husargatan 3, Box 571, SE-75123 Uppsala, Sweden

e-mail: Daniel.Espes@mcb.uu.se

P.-O. Carlsson

Department of Medical Sciences, Uppsala University,

Uppsala, Sweden not protect against loss of C-peptide. Betatrophin treatment in type 1 diabetes would therefore probably not be successful without the use of supraphysiological doses or a combination with immune regulatory treatment.

Keywords Beta cell growth · Betatrophin · Type 1 diabetes

\section{Introduction}

Despite intensive research, there is still no treatment available to prevent loss of beta cells in type 1 diabetes. At disease onset, generally $30-40 \%$ of beta cells remain. Most patients have residual beta cell function for several years, and even up to several decades later $[1,2]$. This suggests the possibility of ongoing renewal of beta cells in patients with type 1 diabetes, or that some of these cells are resistant to immune destruction.

Betatrophin was recently described as a potent stimulator of mouse beta cell proliferation [3]. Moreover, the secreted protein has been detected in human plasma. When overexpressed in mice, a 17 -fold increase in beta cell proliferation was observed [3]. Expression of betatrophin in liver was upregulated in mouse models of type 2 diabetes and during mouse pregnancy. However, specific depletion of beta cells with diphtheria toxin did not cause upregulation, which led the authors to conclude that betatrophin levels are regulated by insulin resistance and not insulin deficiency per se [3].

If these findings in mice were found to be fully applicable in humans, this would open up the possibility of betatrophin treatment in type 1 diabetes. The present study therefore tested the hypothesis that there would be no difference in circulating betatrophin concentrations between healthy individuals and insulin-deficient patients with type 1 diabetes.

\section{Methods}

This study was approved by the Uppsala County regional ethics board, and the reported investigations were carried out 
in accordance with the principles of the Declaration of Helsinki as revised in 2000. All participants were supplied with oral and written information about the study and gave written consent. None had macrovascular complications and all were normotensive without hypertensive treatment. All participants were physically active non-smokers. Healthy age-matched controls $(n=24)$, without a first-degree relative with type 1 diabetes, were recruited by advertising. Of 33 participants with type 1 diabetes, five had onset of diabetes within the preceding 2 years (mean duration $11.2 \pm 4$ months, mean age at onset $24.6 \pm 2.7$ years), whereas the remaining participants $(n=28)$ had a mean disease duration of $19 \pm 1.4$ years and a mean age at onset of $8.1 \pm 1.1$ years.

Blood samples were collected after overnight fasting. Betatrophin levels in plasma were determined with an ELISA (Wuhan Eiaab Science, Wuhan, China; Catalogue No. E11644h). This assay shows linearity for plasma samples when diluted from $1: 2$ to $1: 16$ with a correlation with the known concentration of $85-100 \%$. Spiking with known concentrations of the protein shows a recovery range of $89-105 \%$, and no significant crossreactivity or interference with any other proteins has been observed. All samples were analysed in duplicate. Samples with a CV $>15 \%$ were excluded. Betatrophin levels were confirmed by western immunoblot using a betatrophin primary antibody (Phoenix Pharmaceuticals, Phoenix, USA; WBK-051-55). Plasma samples were depleted of albumin using AlbuVoid Albumin Depletion Kit (Biotech Support Group, Monmouth Junction, NJ, USA). Data were normalised for total protein content. Other variables were analysed at the routine laboratory at Uppsala University Hospital. In patients with undetectable C-peptide concentrations by the standard method (i.e. $<0.003 \mathrm{nmol} /$ ) ), an ultrasensitive C-peptide ELISA (detection range 1.167-130 pmol/l) was used (Mercodia, Uppsala, Sweden).

Statistical analysis was performed using SigmaPlot 12.0. An unpaired two-tailed $t$ test was used to compare differences between the groups. Correlations were determined by linear regression using Pearson product moment correlation. All values are given as mean \pm SEM. $p$ values $<0.05$ were considered significant.

\section{Results}

Betatrophin concentrations were approximately doubled in patients with type 1 diabetes compared with controls (Fig. 1a, b). The validity of the ELISA was confirmed by correlation with signal obtained by western immunoblot in 13 of the samples (Fig. 1c). There were no significant differences in age, BMI, triacylglycerol concentration, LDL-cholesterol concentration, HDL-cholesterol concentration or sex distribution between the two groups, although triacylglycerol levels were, as a mean, $32 \%$ increased in the patients with type 1 diabetes $(p=0.20$; Table 1$)$. Fasting plasma glucose concentrations were higher in the diabetic patients, as were $\mathrm{HbA}_{1 \mathrm{c}}$ and total cholesterol concentrations. In the diabetic patients, there was a tendency to a negative correlation between betatrophin concentration and BMI $\left(r^{2}=0.14\right.$, correlation coefficient $\left.0.29, p=0.10\right)$. There were no correlations between betatrophin concentration and age $\left(r^{2}=0.05, p=0.52\right)$, age at onset of diabetes $\left(r^{2}=0.03\right.$, $p=0.38)$, disease duration $\left(r^{2}=0.01, p=0.60\right), \mathrm{HbA}_{1 \mathrm{c}}\left(r^{2}=8 \times\right.$ $\left.10^{-12}, p=1.0\right)$, fasting plasma glucose concentration $\left(r^{2}=0.06\right.$, $p=0.19)$, insulin requirement $\left(r^{2}=0.05, p=0.19\right)$, triacylglycerol concentration $\left(r^{2}=0.002, p=0.89\right)$, LDL-cholesterol concentration $\left(r^{2}=0.04, p=0.21\right)$, HDL-cholesterol concentration $\left(r^{2}=0.03, p=0.50\right)$ or total cholesterol concentration $\left(r^{2}=0.06\right.$, $p=0.27$ ). In the healthy control group, there was a correlation with age $\left(r^{2}=0.17\right.$, correlation coefficient $\left.0.42, p=0.043\right)$, whereas no correlation between betatrophin concentration and BMI $\left(r^{2}=0.004, p=0.78\right), \mathrm{HbA}_{1 \mathrm{c}}\left(r^{2}=0.27, p=0.13\right)$, fasting plasma glucose $\left(r^{2}=0.04, p=0.34\right)$, triacylglycerol concentration $\left(r^{2}=0.147, p=0.22\right)$, LDL-cholesterol concentration $\left(r^{2}=\right.$ $0.073, p=0.40)$, HDL-cholesterol concentration $\left(r^{2}=0.0009\right.$, $p=0.93)$ or total cholesterol concentration $\left(r^{2}=0.017, p=0.68\right)$ was observed.

All patients with type 1 diabetes were insulin-dependent, and those within 2 years of onset still had detectable fasting C-peptide concentrations $(0.30 \pm 0.05 \mathrm{nmol} / \mathrm{l})$. There was no correlation between residual C-peptide levels and betatrophin levels in the latter $(p=0.89)$. We also found ten individuals $(36 \%)$ among the patients with longer duration of disease with residual detectable fasting C-peptide $(2.8 \pm 0.8 \mathrm{pmol} / \mathrm{l})$, and in this group also there was no correlation between betatrophin and residual C-peptide level $(p=0.61)$. When comparing individuals with residual $C$-peptide with those with undetectable C-peptide, we found no difference in betatrophin concentration (638 \pm 212 vs $791 \pm 240 \mathrm{pg} / \mathrm{ml}), \mathrm{HbA}_{1 \mathrm{c}}(7.7 \pm 0.3 \%$ [60.3 \pm $2.9 \mathrm{mmol} / \mathrm{mol}]$ vs $7.7 \pm 0.3 \%$ [ $60.5 \pm 3.3 \mathrm{mmol} / \mathrm{mol}])$, insulin requirement $\left(0.70 \pm 0.07\right.$ vs $\left.0.66 \pm 0.04 \mathrm{U}[24 \mathrm{~h}]^{-1} \mathrm{~kg}^{-1}\right)$ or BMI $\left(24.2 \pm 0.7\right.$ vs $\left.24.1 \pm 1.1 \mathrm{~kg} / \mathrm{m}^{2}\right)$.

\section{Discussion}

We describe for the first time betatrophin concentrations in humans, and report that circulating concentrations of betatrophin are increased in type 1 diabetes in contrast with what has recently been described in an insulin-deficient mouse model [3]. This indicates that there is already a potential stimulus for beta cell proliferation present in type 1 diabetes, but that this is not sufficient to counteract the decline in Cpeptide levels in the long run.

The reason for increased betatrophin levels in type 1 diabetes is at present not known. A feedback of insulin or C-peptide deficiency, or increased blood glucose concentrations, to increase beta cell mass by betatrophin secretion would 

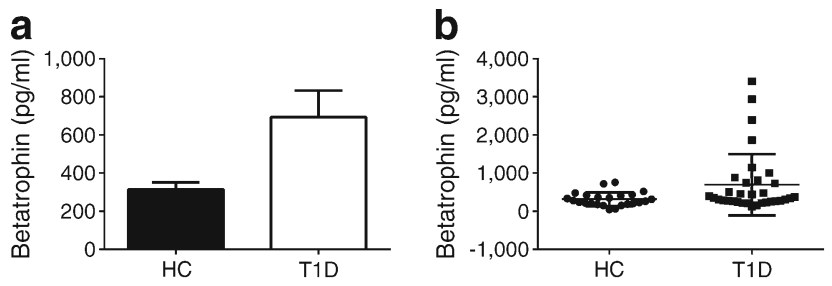

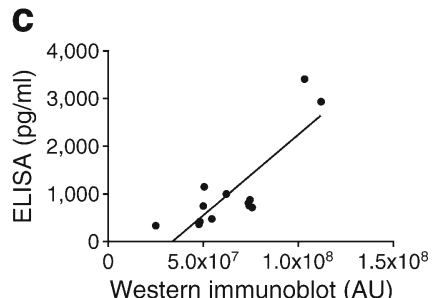

Fig. 1 Increased fasting plasma levels of betatrophin in patients with type 1 diabetes. (a) Plasma concentrations of betatrophin in healthy controls (HC, $n=24)$ and patients with type 1 diabetes (T1D, $n=33$ ) shown as mean \pm SEM. (b) Scatter plot of the individual betatrophin concentrations with mean \pm SEM. (c) Correlation of betatrophin levels obtained by western immunoblot with those obtained by ELISA in 13 of the samples (six HC and seven patients with T1D) showing an $r^{2}$ value of $0.69(p=0.0004)$. Samples were normalised for total protein content, values are arbitrary units (AU). ${ }^{*} p<0.05$

or HDL-cholesterol level differed between the diabetic patients and controls.

Betatrophin belongs to the family of angiopoietin-like proteins. The gene encoding this protein is named C19orf80, and the nutritionally regulated secreting hormone has been given many different names: lipasin, hepatocellular carcinomaassociated protein-TD26, RIFL, angiopoietin-like protein-8 [6-8] and, most recently, betatrophin [3]. Overexpression of betatrophin in mice leads to an increase in serum triacylglycerol, and variations in the gene have been linked with blood lipid levels in humans by genome-wide association studies [6]. However, in our work, we observed no changes in blood lipids that correlated with betatrophin levels. It cannot be excluded that the mean increase in triacylglycerol levels observed in the patients with type 1 diabetes would have been statistically significant in a larger study.

In healthy controls, but not in the patients with type 1 diabetes, plasma betatrophin concentrations were, for unknown reasons, higher in older individuals. It will therefore be interesting in future studies to examine betatrophin concentrations in different age groups.

Post-mortem studies show conflicting results with regard to whether beta cell replication occurs in type 1 diabetes $[9,10]$. If present, increased levels of betatrophin may be a contributing factor. However, although betatrophin is increased in plasma in patients with type 1 diabetes, its concentration does not correlate with metabolic parameters. We cannot exclude the possibility that increased betatrophin levels might have had transient positive effects on beta cell mass early in the disease, or that the decline in residual C-peptide may be exaggerated in the absence of betatrophin. However, in the long run, it does not protect from the progressive loss of C-peptide secretion. An intervention in patients with type 1 diabetes with betatrophin treatment might require supraphysiological dosing as well as combination with immune regulatory treatment.

Acknowledgements V. Armijo del Valle (Uppsala University Hospital, Sweden) is gratefully acknowledged for her skilful assistance, and Mercodia AB for their help with the ultrasensitive C-peptide ELISA. 
Funding The study was generously supported by the Swedish Research Council (K2013-55X-15043), the EFSD/JDRF/Novo Nordisk Programme 2012, AFA Insurance, the Swedish Diabetes Association, the Swedish Juvenile Diabetes Foundation, Olle Engkvist Byggmästare Foundation, the Novo Nordisk Foundation and Diabetes Wellness Sverige.

Duality of interest The authors declare that there is no duality of interest associated with this manuscript.

Contribution statement DE, JL and P-OC conceived and designed the study, and participated in the analysis and interpretation of the data. DE drafted the manuscript, and the other authors revised it critically for intellectual content. All authors approved the final version of the paper.

Open Access This article is distributed under the terms of the Creative Commons Attribution Noncommercial License which permits any noncommercial use, distribution, and reproduction in any medium, provided the original author(s) and the source are credited.

\section{References}

1. Wang L, Lovejoy NF, Faustman DL (2012) Persistence of prolonged C-peptide production in type 1 diabetes as measured with an ultrasensitive C-peptide assay. Diabetes Care 35:465-470
2. Keenan HA, Sun JK, Levine J et al (2010) Residual insulin production and pancreatic ss-cell turnover after 50 years of diabetes: Joslin Medalist Study. Diabetes 59:2846-2853

3. Yi P, Park JS, Melton DA (2013) Betatrophin: a hormone that controls pancreatic beta cell proliferation. Cell 153:747-758

4. Cleland SJ, Fisher BM, Colhoun HM, Sattar N, Petrie JR (2013) Insulin resistance in type 1 diabetes: what is 'double diabetes' and what are the risks? Diabetologia 56:1462-1470

5. Williams KV, Erbey JR, Becker D, Arslanian S, Orchard TJ (2000) Can clinical factors estimate insulin resistance in type 1 diabetes? Diabetes 49:626-632

6. Zhang R (2012) Lipasin, a novel nutritionally-regulated liverenriched factor that regulates serum triglyceride levels. Biochem Biophys Res Commun 424:786-792

7. Quagliarini F, Wang Y, Kozlitina J et al (2012) Atypical angiopoietinlike protein that regulates ANGPTL3. Proc Natl Acad Sci U S A 109: 19751-19756

8. Dong XY, Pang XW, Yu ST et al (2004) Identification of genes differentially expressed in human hepatocellular carcinoma by a modified suppression subtractive hybridization method. Int J Cancer 112:239-248

9. Butler AE, Galasso R, Meier JJ, Basu R, Rizza RA, Butler PC (2007) Modestly increased beta cell apoptosis but no increased beta cell replication in recent-onset type 1 diabetic patients who died of diabetic ketoacidosis. Diabetologia 50:2323-2331

10. Willcox A, Richardson SJ, Bone AJ, Foulis AK, Morgan NG (2010) Evidence of increased islet cell proliferation in patients with recentonset type 1 diabetes. Diabetologia 53:2020-2028 